\title{
APPLICATIONS OF DENDROCHRONOLOGY IN NORTHWESTERN MEXICO
}

\author{
Paula Turkon, Sturt W. Manning, Carol Griggs, Marco Antonio Santos Ramírez, Ben A. Nelson, \\ Carlos Torreblanca Padilla, and Eva Maria Wild
}

\begin{abstract}
Although dendrochronological methods have the potential to provide precise calendar dates, they are virtually absent in Mesoamerican archaeological research. This absence is due to several long-standing, but erroneous, assumptions: that tree rings in this region do not reflect annual growth and environmental variability, that an adequate number of samples do not exist, and that tree-ring measurements cannot be useful without modern trees to link prehispanic chronologies. In this article we present data from the sites of La Quemada and Los Pilarillos, located in the Malpaso Valley, Zacatecas, to demonstrate that suitable archaeologically derived samples of dendrochronologically useful species do exist, that the samples from these sites are measurable and cross-datable, and that the tree rings can yield precise calendar dates using a method that "wiggle-matches" radiocarbon dates on tree-ring sequences. The work demonstrates the potential of these methods to address chronological, and, in the future, climatic questions, which have so far eluded archaeological work in the region.
\end{abstract}

Los métodos dendrocronológicos tienen el potencial de proporcionar fechas de calendario precisas, sin embargo son escasamente utilizados en las investigaciones arqueológicas Mesoamericanas. Esto se debe a la existencia de varios supuestos de larga permanencia, pero erróneos tales como: que los anillos de los árboles en esta región no reflejan el crecimiento anual y la variabilidad medioambiental, que no existe un número adecuado de muestras, y que las mediciones de los anillos de los árboles no pueden ser útiles sin la existencia de árboles modernos para vincular las curvas prehispánico. En este artículo, se presentan datos de los sitios de La Quemada y Los Pilarillos, localizados en el Valle de Malpaso, Zacatecas, para demostrar que existen muestras arqueológicas dendrocronológicamente adecuadas, medibles, que se pueden "crossdate", y que se pueden obtener fechas precisas usando un método llamado "calibración de radiocarbono de secuencias definidas" (radiocarbon wiggle-matching). El trabajo pone en evidencia el potencial de estos métodos para abordar cuestiones cronológicas, y en el futuro, también climáticas, las cuales hasta la fecha han eludido el trabajo arqueológico en la región.

$\mathrm{I}$

n 1944 Edmund Schulman published the first dendrochronology study for Mexico in which he found that some trees, such as Douglas fir (Pseudotsuga menziesii) and some pine species (Pinus spp.), had the potential to be used as chronological timekeepers and to help understand past climate conditions, and that dendrochronological analysis on these samples

Paula Turkon $\square$ Ithaca College, Department of Environmental Studies and Sciences, CNS 257A, 953 Danby Rd., Ithaca, NY 14850, USA (pturkon@ithaca.edu)

Sturt W. Manning and Carol Griggs $\square$ Cornell University, Cornell Tree-Ring Laboratory, B-48 Goldwin Smith Hall, Ithaca, NY 14853-3201, USA

Marco Antonio Santos Ramírez — Instituto Nacional de Antropología e Historia, Calle 10 312, Mérida, Yucatan, Mexico 97118

Ben A. Nelson - Arizona State University, School of Human Evolution and Social Change, 900 S. Cady Mall, Tempe, AZ 85281, USA

Carlos Torreblanca Padilla — Instituto Nacional de Antropología e Historia, Miguel Auza 29, Zacatecas Centro, Zacatecas, Mexico 98000

Eva Maria Wild a University of Vienna, VERA Laboratory, Faculty of Physics, Isotope Research and Nuclear Physics, Währinger Straße 17, A-1090 Vienna, Austria

Latin American Antiquity 29(1), 2018, pp. 102-121

Copyright $(2017$ by the Society for American Archaeology. This is an Open Access article, distributed under the terms of the Creative Commons Attribution licence (http://creativecommons.org/licenses/by/4.0/), which permits unrestricted re-use, distribution, and reproduction in any medium, provided the original work is properly cited.

doi:10.1017/laq.2017.60 
would therefore be a useful tool for archaeologists (Schulman 1944). Scott (1966) reviewed all evidence then available and argued for the potential of dendrochronology in Mexico, including its archaeological sites. Although work was slow to start, much has been achieved with the development of long tree-ring sequences from living and relic trees in Mexico and nearby areas covering the past 1,300 years (Stahle et al. 2011; Stahle et al. 2012; Villanueva Díaz et al. 2002). Archaeological applications have been less successful. With the noted exception of the Casas Grandes region in Chihuahua, Mexico (Bannister and Scott 1962; Scott 1966), and one other very recent exception focused on Maya chronology (Kennett et al. 2013), there have been virtually no successful dendroarchaeological applications published from Mesoamerican archaeological materials.

Indeed, one of the scarce exceptions may largely explain the problem. In his study in conjunction with an archaeological project on the coast of Oaxaca, Naylor (1971) found that even though the environmental conditions seemed ideal, the tree rings he examined were complacent, which means they were not sensitive to environmental variability, an essential component to successful dendrochronology. This pessimistic prognosis seemed to stall dendroarchaeological studies in Mesoamerica for a generation.

Three key things then changed. Over the next 10 to 20 years it became well established that trees growing in extratropical and tropical climatic zones and higher altitudes in Mexico can be used in dendrochronology (Cook and Kairiukstis 1990; Stahle 1999). Second, networks of long tree-ring chronologies were compiled to investigate climate processes that led to renewed attention to both living tree and relic wood sequences in Mexico (e.g., Stahle and Cleaveland 1993), and reliable Mexican tree-ring data were included in the landmark North American Drought Atlas (Cook et al. 2004). Finally, with the turn of the millennium, the Laboratorio Nacional de Dendrocronología of the Instituto Nacional de Investigaciones Forestales, Agrícolas y Pecuarias (INIFAP) was founded. Since then, dendrochronological researchers have successfully developed tree-ring chronologies for many regions of Mexico that date back as much as 1,300 years (Cleaveland et al. 2003; GonzálezElizondo et al. 2005; Stahle et al. 2011; Stahle et al. 2012; Stahle et al. 2016; Villanueva Díaz et al. 2002), and it became possible to investigate specific climate-history associations (e.g., Burns et al. 2014). Despite such major contributions, there have been only two applications of dendrochronology using archaeological wood or charcoal in Mesoamerica (Kennett et al. 2013; Turkon et al. 2015). Perhaps it is the legacy of Naylor's study that thwarted archaeologists from further attempts at dendroarchaeological analysis. Or perhaps its application was impeded due to the belief that archaeological wood samples were too scarce, too small, or too poorly preserved to be useful, or possibly that modern analogues were absent (Evans and Webster 2001:206).

The present article aims to demonstrate the feasibility of dendrochronology in Mesoamerican archaeology, particularly how relatively short tree-ring sequences in small collections of archaeological wood can provide significantly more precise control of time than other available methods. We found that sufficient samples exist, tree rings are discernible and measurable, and their sequences can be dated relative to each other and combined into "floating chronologies." With the integration of the treering ${ }^{14} \mathrm{C}$ wiggle-matching calibration method, these datasets provide important and immediate chronological contributions to the archaeological record of Mesoamerica. In areas such as in the Malpaso Valley of northwestern Mesoamerica, where precise chronological control and finescale reconstruction of past climate conditions have eluded archaeologists, these dendroarchaeological applications may offer one of the only methods that can directly address chronological issues with sufficient precision.

\section{Northern Mesoamerican Frontier Dating Problems}

One of the many theories to explain the northern expansion of the Mesoamerican frontier during the Classic period continues to be accepted today, although there is inconclusive data to support it. This theory suggests that during the Classic period, perhaps around AD 450-500, a group 


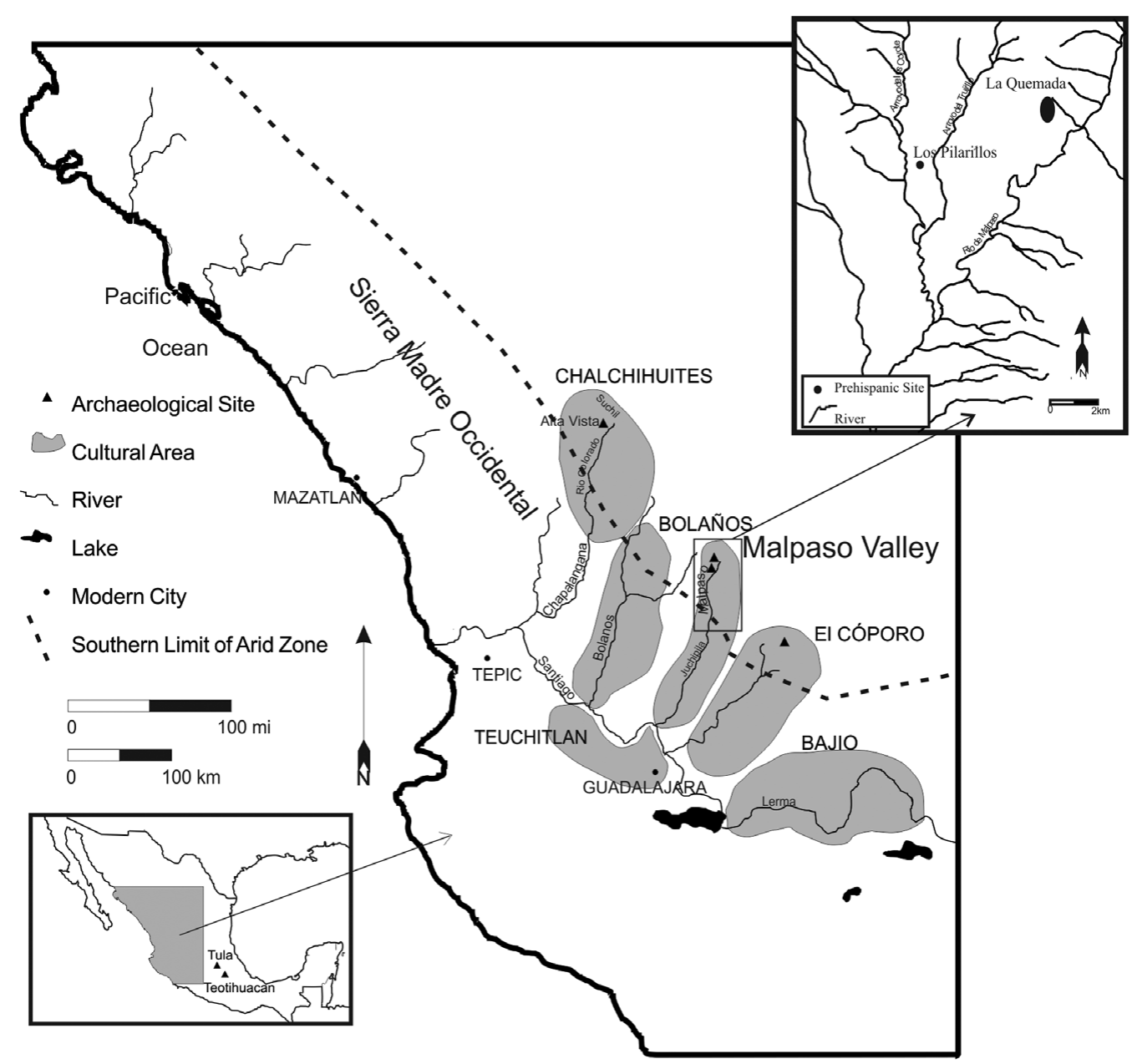

Figure 1. Map of northwest Mexico and the Malpaso Valley, Zacatecas. Figure adapted from Nelson (2001).

of Mesoamerican people moved north because of the opportunity provided by an increase in regional rainfall, which supported an agricultural lifestyle in a region previously too arid (Armillas 1964). This theory also attributes the subsequent abandonment to a drought, or a return to the previous arid conditions, which drove the agriculturally dependent society back into central and west Mexico, perhaps around AD 850 (Figure 1; Armillas 1964; Braniff and Areti-Hers 1998; Parlerm and Wolf 1957).

There are two major problems that have prevented archaeologists from testing and addressing this theory. First, the calibration of single radiocarbon dates, the principal dating method for this region, gives wide ranges of calendar dates that are not precise enough to pinpoint the times of earliest arrival, cultural changes, or abandonment of settlements. This is particularly the case when nearly all dates are from charcoal samples, which can only give the dates after (terminus post quem) the growth of a particular part of a tree with no certainty of the felling year. Overall, in work published to date the available radiocarbon ranges have not been able to resolve a higher-resolution chronology (Beekman 2010; Nelson 1997; Nelson et al. 1997; Soler Arechalde et al. 2011; Trombold 1990). Establishing a more precise chronology by reducing the margins of error would provide a much clearer understanding of the early development of sites and the network of interaction that developed between 
sites through time, ultimately helping to refine the timing of abandonment.

Second, of the studies that directly address the climatic change hypothesis, most indicate that climate conditions were stable during the Classic period (Brown 1992; Elliott et al. 2010; Frederick 1995; Trombold and Israde-Alcantara 2005). The newly established Mexican Drought Atlas (http://drought.memphis.edu/MXDA/) reconstruction is not regarded as robust prior to $\mathrm{AD}$ 1200 for northwest Mexico. Nonetheless, it does indicate a somewhat moister period between $\mathrm{AD}$ 500 and 725 and a several decades-long dry interval in the middle to late eighth century (Stahle et al. 2016; IRI/LDEO Climate Data Library 2016a; IRI/LDEO Climate Data Library 2016b). Although these data are admittedly interpolated from a much wider region, they provide some basis for the climate-driven hypothesis.

Whether or not there were large-scale and long-term climatic changes that could be identified by these studies, there is support from observations in more recent periods, when precipitation is frequently insufficient for subsistence agricultural production (Elliott et al. 2010; Turkon et al. 2011). Indeed, many short to multidecadal dry periods are indicated in various historic and proxy records through the past millennium (Cook et al. 2004; Stahle et al. 2016), suggesting that drought conditions which could have severely affected the stability and longevity of prehispanic agricultural communities in northern Mexico did frequently occur. Archaeological tree-ring evidence may, in the future, offer a means to develop a direct-proxy, tree-ringbased precipitation reconstruction for the Classic period. The incentive is obvious, since the current reconstructions of past environmental conditions are primarily based on alluvial sediments and pollen deposited over long periods of time and do not offer sufficient chronological resolution to identify short to decadal-scale variability.

\section{The Malpaso Valley}

The Malpaso Valley, located on the northern margin of the frontier zone, presents an ideal case for refining the relationship between chronology, climate, and prehispanic settlement through dendroarchaeological analysis. Mean annual rainfall is about $400 \mathrm{~mm}$ (Comisión Nacional del Agua
2008), which provides marginal to sufficient moisture for agriculture (Verheye 2010) but in the event of below normal rainfall becomes marginal or worse.

Like most regions in northwest Mexico, and despite a series of intensive excavations and excellent research, the pace and timing of these cultural developments are still not well understood. The Malpaso Valley, for example, is generally reported to have been occupied between AD 550 and 900 (Beekman 2010; Nelson 1997). Archaeologists have noted that the dividing and remodeling of architectural living space indicates the intensity or duration of use (Lelgemann 2000; Nelson and Schiavitti 1992; Nelson et al. 1993; Nelson et al. 1997), but using this observation to create analytical phases has proven difficult. Similarly, despite major advances in understanding the pottery of the region, the development of a ceramic chronology has been hindered by a lack of chronological precision (Torvinen et al. 2014; Torvinen et al. 2015). It is clear that any advances in chronological control can help address cultural questions, not only within the Malpaso Valley, but also in the regions with which the valley occupants had contact.

Despite the widespread belief that archaeological wood samples are not available in Mexico, we have already collected an adequate number of samples to begin the development of a local tree-ring chronology from two contexts in the Malpaso Valley. The project team is working on other contexts as well. The two contexts discussed below, however, have the greatest number of samples and have received the most attention to date. Other contexts will be presented in future publications.

La Quemada Cuartel. La Quemada is the largest site in the Malpaso Valley (Figure 2). It is located on a rocky mountain outcrop overlooking the valley floor. The monumental public architecture includes a Hall of Columns (a temple), a ball court, a votive pyramid, and a road system that connects La Quemada to many outlying sites. Combined with the extensive renovation of the sloping mountain into more than 50 level terraces, these features suggest La Quemada played a primary role in the valley. Although more than 50 years of research have provided an excellent 


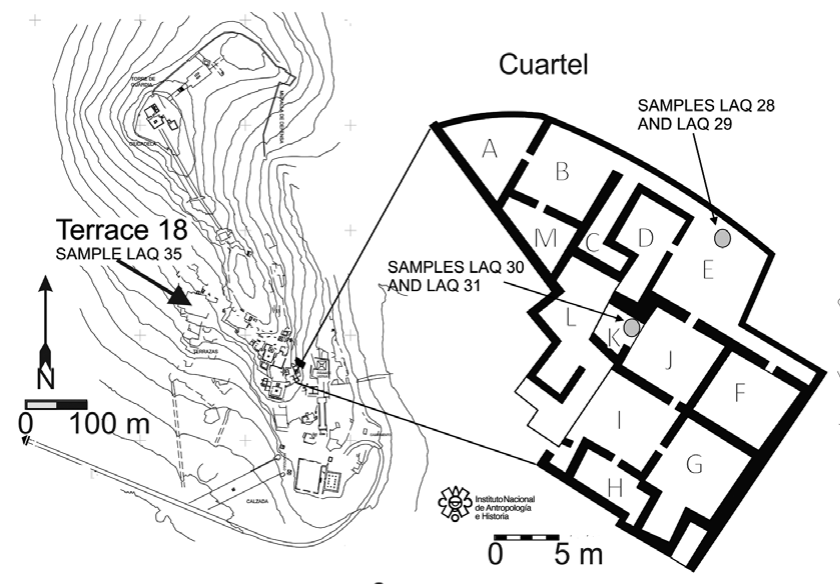

a.

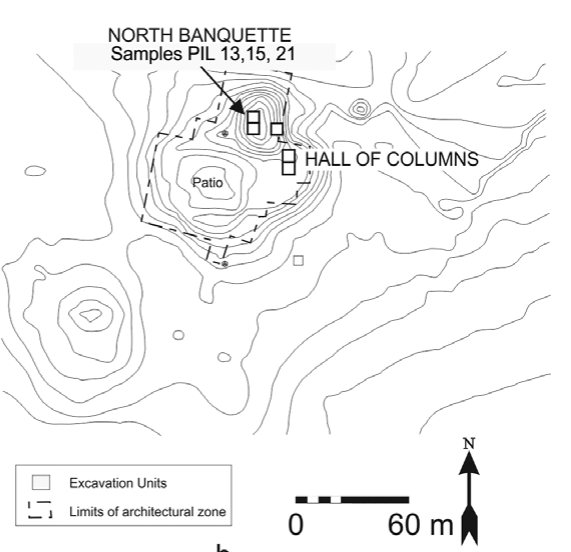

b.

Figure 2. Topographic map of (a) La Quemada and (b) Los Pilarillos, Zacatecas, Mexico. Adapted from Plano Fotométrico de la Ciudadela La Quemada Versión Armillas-Weigand (Nelson 1997); Cuartel image from Santos Ramírez (2014).

understanding of the construction and change in architectural structures, artifacts, human bone, social organization, food systems, and trade networks (some review articles include Beekman [2010], Nelson [2004], Trombold [1985], and Weigand [1977]), each one of these studies could be greatly enhanced by a more precise control of time.

The Cuartel is a room complex overlooking the central site core. In the 1950s and 1960s Pedro Armillas conducted excavations in the Cuartel (Armillas 1963; Trombold 1990). Most of his records are now lost, but his artifact collection is intact and undergoing analysis at Arizona State University. Numerous wood samples were collected during these excavations, but due to the passage of time since excavation, most are in very poor condition and their fragments generally have short ring counts. One sample, however (INAH 16), still had more than 40 rings and is discussed below.

Recent excavations in adjacent rooms, directed by Marco Antonio Santos Ramírez in 2012-2014, provide more in-depth understanding of this room complex (Santos Ramírez 2014). The complex had two major construction phases. The oldest, a single-story structure in the shape of a half-moon, was relatively small and likely ceremonial in function. The space was later remodeled into a two-story masonry structure, different than the adobe found in most other sectors of the site. The generally more substantial construction materials and high frequency of fine ceramics suggest that this area housed an elite population (Jiménez Betts 2004; Santos Ramírez 2014). The 13 interconnected rooms on the ground floor were closed to the public and intentionally separated, perhaps for separate governing lineages. The upper floor seems to have been used for more public social activities (Santos Ramírez 2014). Some fallen beams, probably used as roof supports between the two floors, were found within these rooms. The beams were very well preserved, some partially charred, along the still-plastered walls (Notimex 2013). These beams, along with some of the wood recovered by Armillas discussed above, provide the first assemblage for dendrochronological applications (samples INAH 16 and LAQ 28-32).

Los Pilarillos Hall of Columns. Los Pilarillos is located on the valley floor at the confluence of two arroyos (Figure 2). Although substantially smaller than La Quemada, it appears to have been an important site. It is connected by a number of roads, and like elite construction areas at $\mathrm{La}$ Quemada, has formal masonry architecture on at least one side of a large sunken plaza. Excavations conducted by Nelson in the 1990s revealed a building analogous to the Hall of Columns found at La Quemada and other important sites on 

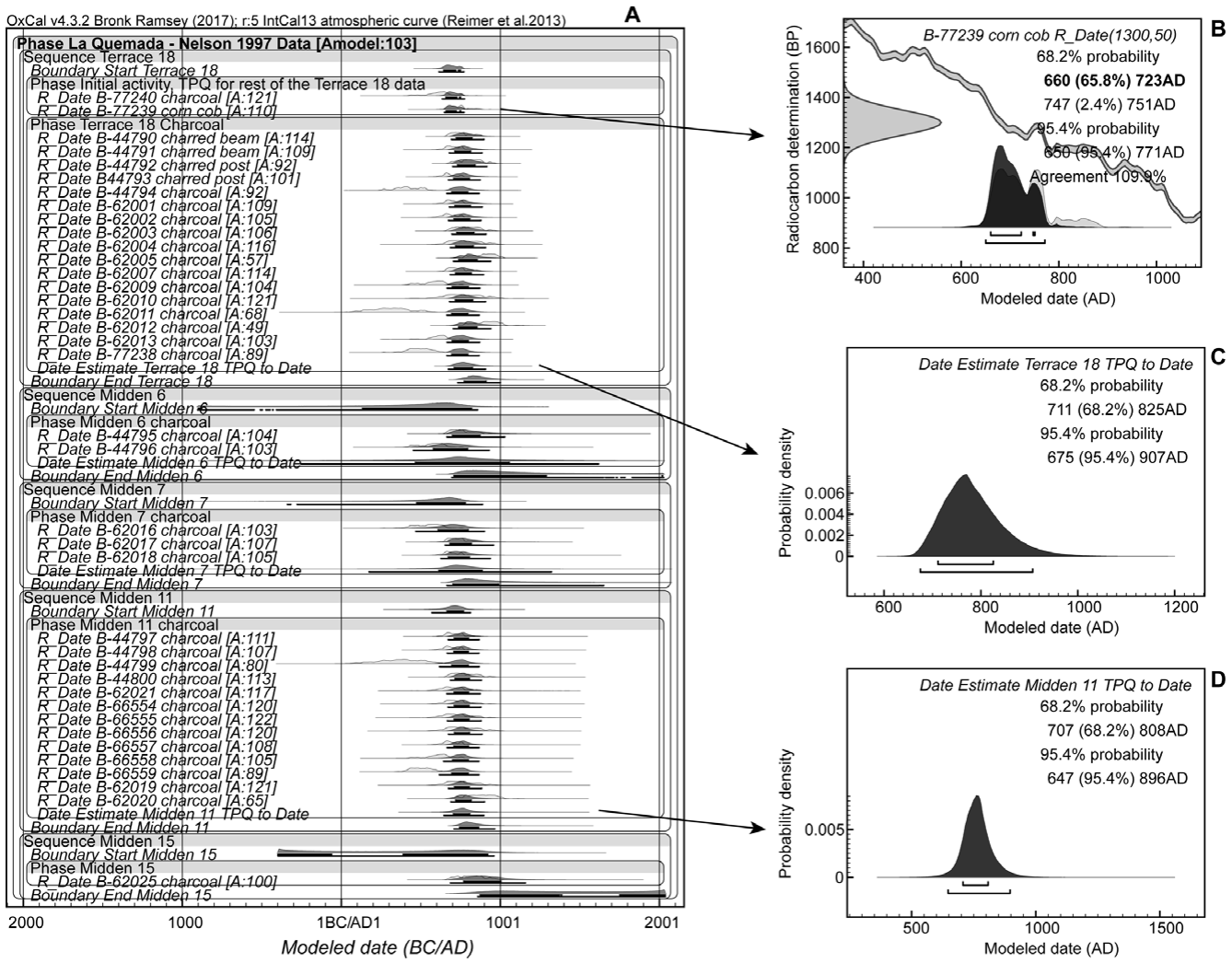

Figure 3. A reanalysis of the radiocarbon data for La Quemada in Nelson (1997) using Bayesian chronological modeling employing OxCal (Bronk Ramsey 2009a, 2009b) and IntCal13 (Reimer et al. 2013).

the northern frontier (Torreblanca Padilla 2014), and a carefully constructed high mound on the North Banquette, which may have supported a small pyramid and adjacent rooms (called North and East Rooms; Nelson and Schiavitti 1992; Nelson et al. 1993). Charred beam fragments were recovered among the adobe blocks, stone remains, and reeds in the fill above the floors of these rooms. These fragments make up a charcoal assemblage of 33 discrete samples.

Until now, best efforts to date the two sites have employed radiocarbon data that have only led to broad chronological estimates-for example, AD 550-800 (Nelson 1997:103-105). Employing a Bayesian chronological modeling approach (Bronk Ramsey 2009a, 2009b; Zeidler et al. 1998), today we can do a little better. Figure 3 illustrates a reanalysis of the Nelson (1997) dates from La Quemada, which results in a largely similar main phase terminus post quem (TPQ) for the two main datasets from
Terrace 18 and Midden 11, respectively, cal AD 711-825 and cal AD 707-808 at 68.2\% highest posterior density (HPD). The initial phase shortlived sample (B-77239, a corncob) sets a TPQ for the data in the model and is likely placed at $\mathrm{AD}$ 660-723. These dates suggest a more restricted age range for the site compared to previous estimates (AD 550-800).

\section{Lab Methods and Analysis}

\section{Basic Principles of Dendrochronology}

Dendrochronological analysis is based on two basic principles (Fritts 1976; Schweingruber 1988; Speer 2010). First, tree species suitable for dendrochronology produce one visible tree ring per year as the response to growth conditions. Each annual tree ring usually includes a rapid growing season when conditions are favorable, producing earlywood, and one of more slow 
growth, called latewood, with a dormant phase with no growth between each annual increment. These changes are evident in fluctuations in tissue density, color, and cell size within each ring. The number of annual rings in the cross section of a tree records the biological age of the tree. The outermost ring in a sample represents the last year of growth. Bark or waney edge, the ring immediately below bark, represents the year in which the tree was cut down, and its presence is important for archaeological interpretation.

Second, annual-ring widths vary in response to changing climatic and environmental factors, such as temperature and rainfall, producing wider rings when conditions are favorable and narrower rings when conditions are poor (Fritts 1976). Despite individual circumstances and histories, trees of the same species in the same geographic area under similar climatic and environmental constraints produce over time similar ring-width growth patterns. Bringing the two basic principles together, dendrochronology matches the unique growth pattern between trees and site chronologies to relatively date them against each other.

Breaking down the two principles, a successful application of dendrochronology requires the following preconditions: (1) tree species with annual growth rings, (2) multiple samples per species, (3) generally 50 or more rings per sample, (4) trees that grew in the same climatic region, (5) trees that grew during the same time period, and (6) growth response mainly associated with climate and not specific microscale environmental conditions. When sampling multiple living trees, all but the last are usually immediately apparent. In an archaeological setting, however, all six preconditions must be considered.

In order to address the preconditions of archaeological wood samples for dendrochronological analysis, a clear view of the ring boundaries and cells on the transverse surface is necessary to evaluate annual-ring growth, ring count, and species identification. Sketches and photographs of the samples are taken before sample preparation because the preparation process is partially destructive. Wood segments of unburned timbers are prepared by sanding the transverse surface to a high polish with a pro- gressive series of coarse to very fine sandpapers. Charred samples are prepared by sanding or scraping with a fine razor and blowing away the dust. If the sample is fragile, it is prepared by snapping it to create a fresh break. After preparation, samples are inspected under stereo, or dissecting, microscopes or scanning electron microscopes to identify genus and species, if possible, and to make an initial ring count. Genera and subgenera types of species are classified using anatomical characteristics, primarily on the basis of the transverse surfaces.

All samples in our collection have annual rings, meeting precondition 1 . Precondition 2, multiple samples of the same species, is minimally fulfilled and cautiously accepted, as explained below. Of the assemblage, 17 of the samples contain more than the $\sim 50$ rings required in precondition 3. Precondition 4 is met by the restrictions in transport technology at the time, giving a high probability that the trees felled for construction were all from the same climate zone in the Malpaso Valley. Additional confirmation of preconditions 5 and 6 are generally supported by the analysis as presented in the results sections below.

Due to poor preservation and friable conditions, species-specific attributes are difficult with archaeological wood remains, especially when charred. In addition, many pine species have similar wood anatomical features that are not diagnostic at species level (Schweingruber 1988). In the state of Zacatecas, there are currently 12 species and varieties of pine, with successful hybridization between many (Martínez 1948), and more species were likely during the occupation of the site. Although we hesitate to identify the archaeological samples to the species level, all are pines. We conservatively identified four subgenera types by differences in the abruptness of early- to latewood transition, the width of latewood, and the distribution and size of resin ducts (Table 1). There are at least four samples of each type in our collection.

\section{Measuring and Cross-Dating Samples}

For the La Quemada and Los Pilarillos collections, all samples with ring counts greater than 40 were measured using a standard binocular microscope and measurement stage at $0.01 \mathrm{~mm}$ 
Table 1. Description of Samples from the La Quemada and Los Pilarillos Sites.

\begin{tabular}{|c|c|c|c|c|c|c|c|}
\hline \multirow[b]{2}{*}{ Site } & \multirow{2}{*}{$\begin{array}{l}\text { Sample } \\
\text { Number }\end{array}$} & \multirow{2}{*}{$\begin{array}{l}\text { Number } \\
\text { of Rings }\end{array}$} & \multirow{2}{*}{$\begin{array}{l}\text { Maximum } \\
\text { Dimension } \\
(\mathrm{cm})^{\mathrm{a}}\end{array}$} & \multicolumn{2}{|c|}{$\begin{array}{l}\text { Relative Years } \\
(\mathrm{RY})^{\mathrm{b}}\end{array}$} & \multirow{2}{*}{$\begin{array}{l}\text { Type of } \\
\text { Pine }^{c}\end{array}$} & \multirow{2}{*}{$\begin{array}{l}\text { Charcoal } \\
\text { or Wood }\end{array}$} \\
\hline & & & & Begin & End & & \\
\hline LAQ & 31 & 174 & $11 \mathrm{D}, 30 \mathrm{~L}$ & 830 & 1003 & III & W \\
\hline LAQ & 35 & 39 & 4 & 987 & 1025 & III & $\mathrm{C}$ \\
\hline LAQ & 28 & 58 & 9D & 1018 & 1075 & I & $\mathrm{C}$ \\
\hline LAQ & 29 & 41 & $11 \mathrm{D}$ & 1029 & 1068 & I & $\mathrm{C}$ \\
\hline LAQ & 30 & 91 & $14 \mathrm{D}, 30 \mathrm{~L}$ & 1001 & 1090 & I & $\mathrm{C}$ \\
\hline LAQ & 16 & 56 & $\mathrm{D}>8$ & 1079 & 1134 & & $\mathrm{C}$ \\
\hline LAQ & 27 & 48 & $10 \mathrm{D}, 12 \mathrm{~L}$ & & & I & $\mathrm{C}$ \\
\hline LAQ & 32 & 77 & 10 & & & I & W \\
\hline LAQ & 43 & 46 & $\mathrm{D}>7$ & & & & $\mathrm{C}$ \\
\hline PIL & 13 & 126 & 5 & 1029 & 1134 & II & $\mathrm{C}$ \\
\hline PIL & 21 & 78 & 5 & 1057 & 1133 & II & $\mathrm{C}$ \\
\hline PIL & 15 & 71 & 6 & 1009 & 1069 & II & $\mathrm{C}$ \\
\hline PIL & $1 \& 28$ & 76 & 7 & & & II & $\mathrm{C}$ \\
\hline PIL & 14 & 40 & 3.5 & & & IV & $\mathrm{C}$ \\
\hline PIL & 16 & 40 & 5 & & & III & $\mathrm{C}$ \\
\hline PIL & 17 & 72 & 3 & & & IV & $\mathrm{C}$ \\
\hline PIL & 22 & 53 & 4 & & & III & $\mathrm{C}$ \\
\hline PIL & 24 & 89 & 4 & & & IV & $\mathrm{C}$ \\
\hline PIL & 27 & 73 & 4.5 & & & II & $\mathrm{C}$ \\
\hline PIL & 29 & 70 & 4.5 & & & IV & $\mathrm{C}$ \\
\hline PIL & 30 & 53 & 4 & & & IV & $\mathrm{C}$ \\
\hline PIL & 31 & 59 & 3.5 & & & II & $\mathrm{C}$ \\
\hline PIL & 32 & 48 & 4 & & & II & $\mathrm{C}$ \\
\hline PIL & 33 & 50 & 5 & & & IV & $\mathrm{C}$ \\
\hline
\end{tabular}

${ }^{\mathrm{a}}$ The widest part of the sample, or diameter and length if noted.

${ }^{b}$ Relative dates to each other, based on cross dates. Tentative cross dates are italicized.

${ }^{c}$ Type I: abrupt earlywood-latewood (EW-LW) transition, narrow LW, resin ducts throughout rings; Type II: gradual EW-LW transition, wide LW, numerous large resin ducts; Type III: gradual EW-LW transition, narrow LW, very occasional ducts mainly in LW; Type IV: abrupt EW-LW and wide LW, resin ducts mainly in LW, smaller and less numerous than Type II.

precision. Ring widths were measured twice along each radius, with a minimum of two radii per sample. Measurements were carefully reconciled within single sample sequences and their radii combined before attempting to cross-date with the tree-ring sequences of other samples, and additionally reconciled when missing or false rings were apparent in between-sample comparisons. For samples that had many fragments from the same tree, the larger fragments were measured and the resulting measurements combined when visible characteristics of ring patterns could be fit together.

The ring-width sequences in samples from the same site and contexts were compared for possible cross dating, using the established dendrochronological methods of visual compari- son, distinctive marker years, and supporting statistical tests (Cook and Kairiukstis 1990), including Student's t-score, intercorrelation, and trend coefficients provided by Tellervo and COFECHA software (Brewer 2014; Holmes 1983). A trend coefficient is the percentage of increases or decreases in year-to-year ring widths that are the same in the overlap between samples. Successfully cross-dated samples in the same context were combined into chronologies. The chronologies and single samples from different contexts were then compared, and again, if any of those sequences cross-dated successfully, those datasets were combined. Once the chronologies were compiled for each site, they were compared with each other and with samples that lacked successful within-site cross dating. By this method, 
we could determine if the two sites were occupied at the same time.

\section{Placing Floating Tree-Ring Chronologies in Absolute Time}

The methods described above demonstrate how a tree-ring chronology is constructed. When an archaeological chronology is produced for a species, time period, and geographic region for which there are no established calendar-dated reference chronologies to place it in absolute time, then it is considered a "floating chronology." A radiocarbon date on samples used in the chronology can place the chronology approximately in time. A tree-ring radiocarbon "wigglematch," however, achieves a more specific and precise placement with a much smaller relative error (Bayliss 2007; Bronk Ramsey et al. 2001; Galimberti et al. 2004).

Our tree-ring chronologies give relative dates of the tree rings in the timbers from several cultural contexts at the two sites and suggest their chronological order relative to each other. Since there are no reference chronologies, they are floating in time. The wiggle-match method helps to obtain the absolute dates by creating a dataset of multiple ${ }^{14} \mathrm{C}$ dates separated by the number of rings between the dated tree-ring segments. For this purpose, after cross-dated sequences were combined into chronologies, samples were chosen for ${ }^{14} \mathrm{C}$ dating. Generally, one or two samples were chosen from each chronology, plus single samples chosen for their long ring sequences or culturally meaningful contexts. From each sample, a series of decadal-scale sequential ring segments were selected and cut for radiocarbon dating. For each wiggle-match, a dataset was compiled of the ${ }^{14} \mathrm{C}$ dates placed along the same timeline as their respective segments and fitted to the IntCal13 northern hemisphere international radiocarbon calibration curve (Reimer et al. 2013) using the D_Sequence function in the OxCal software (Bronk Ramsey et al. 2001). The results of wiggle-matches are reported by quoting the mean \pm sigma $(\mu \pm \sigma)$ of the modeled probability distribution of the wigglematch. Ranges, when cited, are for the $68.2 \%$ (and 95.4\%) highest posterior density (HPD) intervals (n.b., these are not $1 \sigma$ [and $2 \sigma$ ] ranges because the calibrated and/or modeled ranges are not symmetrical probability distributions). The success of a wiggle-match depends on identifying a unique fit, which is typically affected by the length of the sequence, number of tree-ring sequenced data, and the shape of the radiocarbon calibration curve in the relevant period.

\section{Determining the Years of Construction and Occupation}

Determining the year in which a tree was felled is the key to establishing construction dates and occupation range. The outermost ring, indicated by the presence of bark or waney edge, is the last ring of growth and the year in which the tree died.

Once the tree-ring datasets have been absolutely dated, the construction and occupation dates are determined by the end dates of the samples. For each sample, if the outermost growth ring is at the waney edge, then the date of its outer ring is the felling date and indicates the earliest date range for the cultural use of the tree. For timbers found at archaeological sites, however, the waney edge is frequently missing due to preparation of the wood for construction or natural decay. So the dates of the outer extant ring in these samples give a "felled after" date (TPQ), indicating that construction had to be later than that year.

\section{Results}

Here we present the initial results of the dendrochronological and radiocarbon wigglematching methods for the Malpaso Valley sites of Los Pilarillos and La Quemada. We begin with the dendrochronological results for each structural context, then compare contexts within each site. Next, we compare the two sites. Finally, we present the results as absolute dates by considering radiocarbon assays and the wiggle-match analysis.

\section{Cross-Dated Samples from within Sites in the Malpaso Valley}

La Quemada. We collected seven samples from the 2012-2014 Cuartel excavations at $\mathrm{La}$ Quemada (LAQ) and inspected 22 more stored from the Armillas excavations in the 1960s. One additional sample was collected from the temple on Terrace 18 (Figure 2). Most of the 


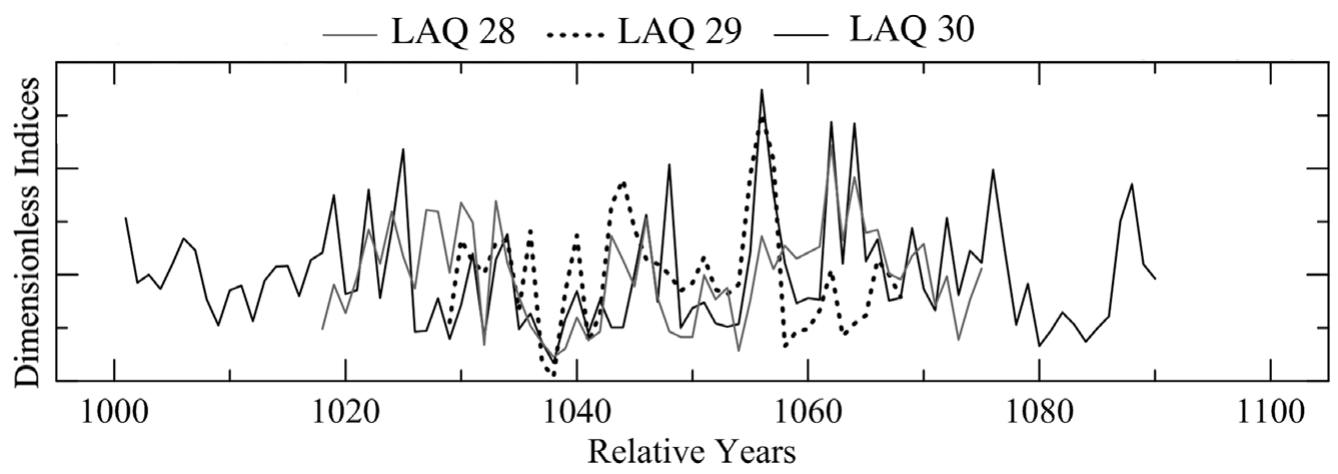

Figure 4. Cross-dated tree-ring sequences of three samples (LAQ 28-30) representing two pine species from the La Quemada Cuartel, Malpaso Valley, Zacatecas, Mexico.

samples in the Armillas collection had disintegrated, and only two had enough rings to meet precondition 3. The $10 \mathrm{La}$ Quemada samples that meet most of the preconditions discussed above represent two pine types, Types I and III, and five samples have more than 50 rings (Table 1 ).

Three samples from the Cuartel (LAQ 28 and 29 from Room E and LAQ 30 from Room K) cross-dated and were combined to form a $\mathrm{La}$ Quemada chronology that is 90 years in length (Figure 4). All are Type I pines. The outer rings of both samples from Room $\mathrm{E}$ are continuous along most of their circumferences, suggesting the rings were very close to the last growth ring before the tree was felled. This implies that the construction of Room E occurred in relative year (RY) 1075 or very soon after. The cross-dated sample from Room K ends in RY 1090, and its outer ring is also very close to the waney edge, indicating that the wood was cut not long after RY 1090, putting the date of construction for Room $\mathrm{K}$ about 15 years after the construction of Room E. An additional sample from Room K, LAQ 31, is of Type III species and does not cross-date with the others but is discussed later.

At Terrace 18, the sample LAQ 35, a Type III pine, has only 39 rings, which makes cross dating questionable. Nevertheless, we highlight it here as it may be an important bridge between other samples from the site and because it was found in a different context (Table 1). We discuss it in terms of wiggle-matching later. Similarly, LAQ 16, from the original Armillas Cuartel collection, has 56 rings and pro- vides an important time marker for the Cuartel occupation.

Los Pilarillos. Thirty-three samples were collected from three areas at Los Pilarillos, the North and East Rooms in the North Banquette and from the East Banquette. All samples are of pine species Types II and IV. Each sample was broken, some with as many as 14 fragments. Twelve samples have more than 50 rings and are close to meeting the minimum preconditions for dendrochronological analysis.

Two samples from the North Room of the North Banquette (PIL 13 and PIL 21) are of Type II pines and cross-date, ending only a year apart (Figure 5). Neither sample has a definitive waney edge, but since their outer ring dates are within a year of each other, and the rings extend around $25 \%$ of their circumferences, it is logical to think that they were cut at the same time. The samples were combined into a Los Pilarillos chronology, 106 years in length.

PIL 15, also from the North Room of the North Banquette and of Type II pine, is composed of two measured fragments, neither of which suggests a close proximity to a waney edge. The lack of waney edge indicates that we can only give the outer ring a "felled after" date. The average ring width, about $0.2 \mathrm{~mm}$, is so small that many rings easily could have broken off.

\section{Cross Dating between Malpaso Valley Sites}

The successful cross dating within each of the two Malpaso Valley sites indicate that cross 


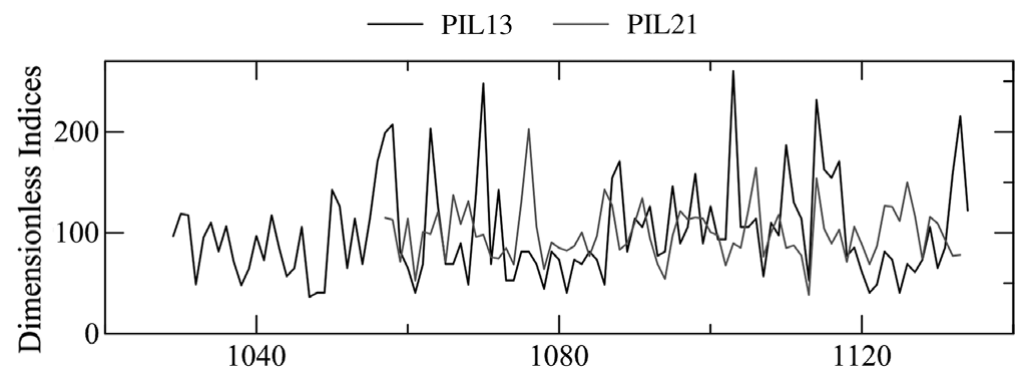

Figure 5. Cross-dated tree-ring sequences of two samples (PIL 13 and PIL 21) from two contexts at Los Pilarillos, Malpaso Valley, Zacatecas, Mexico.

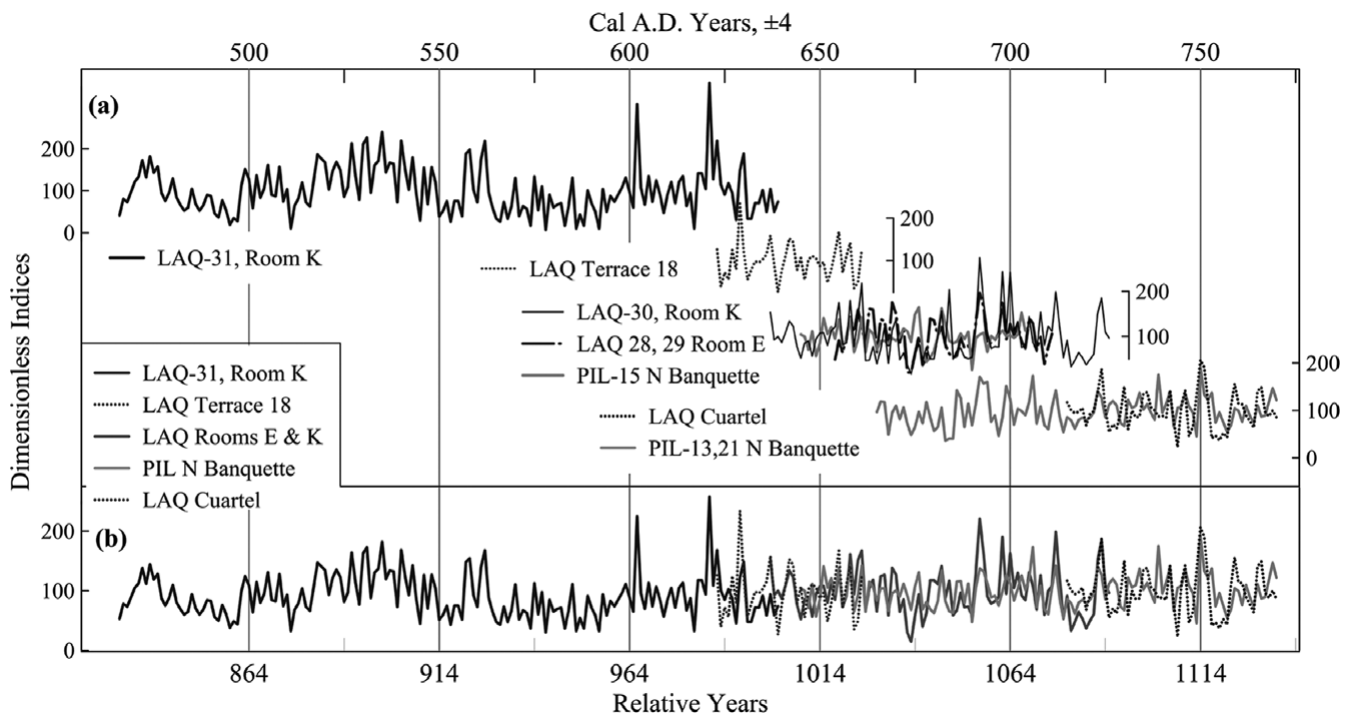

Figure 6. Cross-dated sequences from samples from La Quemada and Los Pilarillos. (a) Relative dates of samples from La Quemada and Los Pilarillos. Dotted lines indicate tentative cross dates due to very short overlaps. Placement is validated by ${ }^{14} \mathrm{C}$ dates. (b) The same sample chronologies plotted along a single axis.

dating should be possible between Los Pilarillos and La Quemada and, if so, would be an indication that their occupations were contemporaneous. This between-site cross dating was confirmed, with good statistical support, by matching growth patterns in the La Quemada chronology with the Los Pilarillos chronology (Figure 6). The cross date also indicates that the two species, Types I and II, respond similarly to the same climate parameters. This cross date puts the end date of the Los Pilarillos chronology at RY 1134, ending 44 years later than the La Quemada chronology.

An additional cross date was successful between the La Quemada and Los Pilarillos chronologies and a single sample, PIL 15, also from the Los Pilarillos North Banquette, ends at RY 1069, 65 years earlier than the Los Pilarillos chronology. Due to the short 41 years of overlap, the relative cross date of the two Los Pilarillos sequences had not been identified when initially comparing the Los Pilarillos samples. Adding PIL 15 to the original Los Pilarillos chronology of PIL 13 and 21 creates a revised 126-year chronology that increases the visual similarity and supporting statistics with the La Quemada chronology (Figure 6, Table 2).

Finally, the placement of a second tentative cross date between LAQ 16 and the Los Pilarillos chronology is supported by ${ }^{14} \mathrm{C}$ wiggle-matching (Tables 2 and 3, Figures 6 and 8). LAQ 16 and 
Table 2. Supporting Statistics for Cross Dating between La Quemada and Los Pilarillos Samples and Sites.

\begin{tabular}{|c|c|c|c|c|c|}
\hline Averages & $T$-score & $\begin{array}{l}\text { Correlation } \\
\text { Coefficient }\end{array}$ & $\begin{array}{l}\text { Trend } \\
\text { Coefficient }\end{array}$ & Overlap & $P$-value \\
\hline \multicolumn{6}{|l|}{ Within Sites } \\
\hline LAQ 28, 29, 30 & 3.95 & 0.51 & 75.1 & 50 & 0.05 \\
\hline PIL 13, 22 & 4.26 & 0.44 & 59.9 & 77 & 0.05 \\
\hline PIL 13, 22 vs. 15 & 2.02 & 0.31 & 58.7 & 41 & 0.10 \\
\hline \multicolumn{6}{|l|}{ Between Sites } \\
\hline LAQ 28, 29, 30 vs. PIL 13, 22 & 4.84 & 0.53 & 76.7 & 61 & 0.01 \\
\hline LAQ 28, 29, 30 vs. PIL 15 & 4.18 & 0.48 & 74.6 & 62 & 0.01 \\
\hline LAQ $28,29,30$ vs. PIL 13, 15, 22 & 6.24 & 0.57 & 75.3 & 82 & 0.01 \\
\hline PIL 13, 15, 22 vs. LAQ 16 & 1.91 & 0.25 & 67.3 & 56 & 0.10 \\
\hline
\end{tabular}

Table 3. Radiocarbon Dates of Segments from Four La Quemada and Two Los Pilarillos Samples.

\begin{tabular}{|c|c|c|c|c|c|c|c|}
\hline \multirow[b]{2}{*}{${ }^{14} \mathrm{C}$ Lab, Number } & \multirow[b]{2}{*}{ Cornell \# } & \multirow[b]{2}{*}{${ }^{14} \mathrm{C}$ Age } & \multirow[b]{2}{*}{${ }^{14} \mathrm{C} 1 \sigma$} & \multirow[b]{2}{*}{$\delta^{13} \mathrm{C}$} & \multicolumn{2}{|c|}{ Relative Years (AD) } & \multirow{2}{*}{$\begin{array}{l}\text { Wood or } \\
\text { Charcoal }\end{array}$} \\
\hline & & & & & Begin & End & \\
\hline & LAQ 31 & & & & 830 & 1003 & $\mathbf{W}$ \\
\hline VERA-6188 & LAQ 31-1 & 1586 & 28 & -19.8 & 830 & 840 & \\
\hline VERA-5975A & LAQ 31-2 & 1617 & 30 & -22.7 & 852 & 862 & \\
\hline VERA-5975B & LAQ 31-3 & 1608 & 30 & -22.3 & 852 & 862 & \\
\hline VERA-6189 & LAQ 31-4 & 1565 & 28 & -19.7 & 874 & 884 & \\
\hline VERA-5976 & LAQ $31-5$ & 1556 & 35 & -20.9 & 896 & 906 & \\
\hline VERA-5977A & LAQ 31-6 & 1482 & 31 & -23.5 & 940 & 950 & \\
\hline VERA-5977B & LAQ 31-7 & 1501 & 31 & -21.2 & 940 & 950 & \\
\hline VERA-5978 & LAQ 31-8 & 1453 & 30 & -21.9 & 984 & 994 & \\
\hline \multirow[t]{2}{*}{ VERA-6190 } & LAQ 31-9 & 1407 & 25 & -22.5 & 995 & 1003 & \\
\hline & LAQ 35B all & & & & 987 & 1026 & $\mathbf{C}$ \\
\hline VERA-6204 & LAQ 35B-1 & 1417 & 26 & -25.4 & 987 & 999 & \\
\hline VERA-6205 & LAQ 35B-2 & 1372 & 28 & -26.9 & 1000 & 1009 & \\
\hline \multirow[t]{2}{*}{ VERA-6206 } & LAQ 35B-3 & 1390 & 28 & -25.3 & 1011 & 1026 & \\
\hline & PIL 15 all & & & & 1009 & 1069 & $\mathbf{C}$ \\
\hline VERA-6197 & PIL 15F-1 & 1365 & 32 & -25.6 & 997 & 1001 & \\
\hline VERA-6198 & PIL 15F-2 & 1346 & 25 & -22.7 & 1002 & 1009 & \\
\hline VERA-6199 & PIL 15F-3 & 1399 & 23 & -25.5 & 1011 & 1020 & \\
\hline VERA-6200 & PIL 15F-4 & 1328 & 29 & -26.9 & 1023 & 1032 & \\
\hline VERA-6201 & PIL 15F-5 & 1333 & 25 & -24.6 & 1033 & 1047 & \\
\hline VERA-6202 & PIL 15F-6 & 1283 & 26 & -23.9 & 1048 & 1062 & \\
\hline \multirow[t]{2}{*}{ VERA-6203HS } & PIL 15J-7 & 1310 & 28 & -24.4 & 1063 & 1069 & \\
\hline & LAQ 28 all & & & & 1018 & 1075 & $\mathbf{W}$ \\
\hline VERA-6194 & LAQ 28-1 & 1306 & 22 & -21.4 & 1036 & 1045 & \\
\hline VERA-6195 & LAQ 28-2 & 1356 & 22 & -19.7 & 1046 & 1055 & \\
\hline \multirow[t]{2}{*}{ VERA-6196 } & LAQ 28-3 & 1312 & 22 & -21 & 1066 & 1075 & \\
\hline & PIL 13 & & & & 1029 & 1134 & C \\
\hline \multirow[t]{2}{*}{ VERA-5979 } & PIL 13-1 & 1262 & 30 & -25.2 & 1130 & 1134 & \\
\hline & LAQ 16 & & & & 1079 & 1134 & C \\
\hline AA98657 & LAQ 16-1 & 1255 & 37 & -26.6 & 1079 & 1088 & \\
\hline AA98658 & LAQ 16-2 & 1261 & 27 & -26.2 & 1119 & 1128 & \\
\hline
\end{tabular}

the outer two samples of the PIL chronology all contain close-to-waney edges and end at approximately the same year, RY 1134, suggesting their construction occurred around the same time.

\section{Wiggle-Matches and Placement of Single}

\section{Samples}

The dendrochronological analysis provides relative dates of construction at the two sites and gives them contemporaneity and chronological 


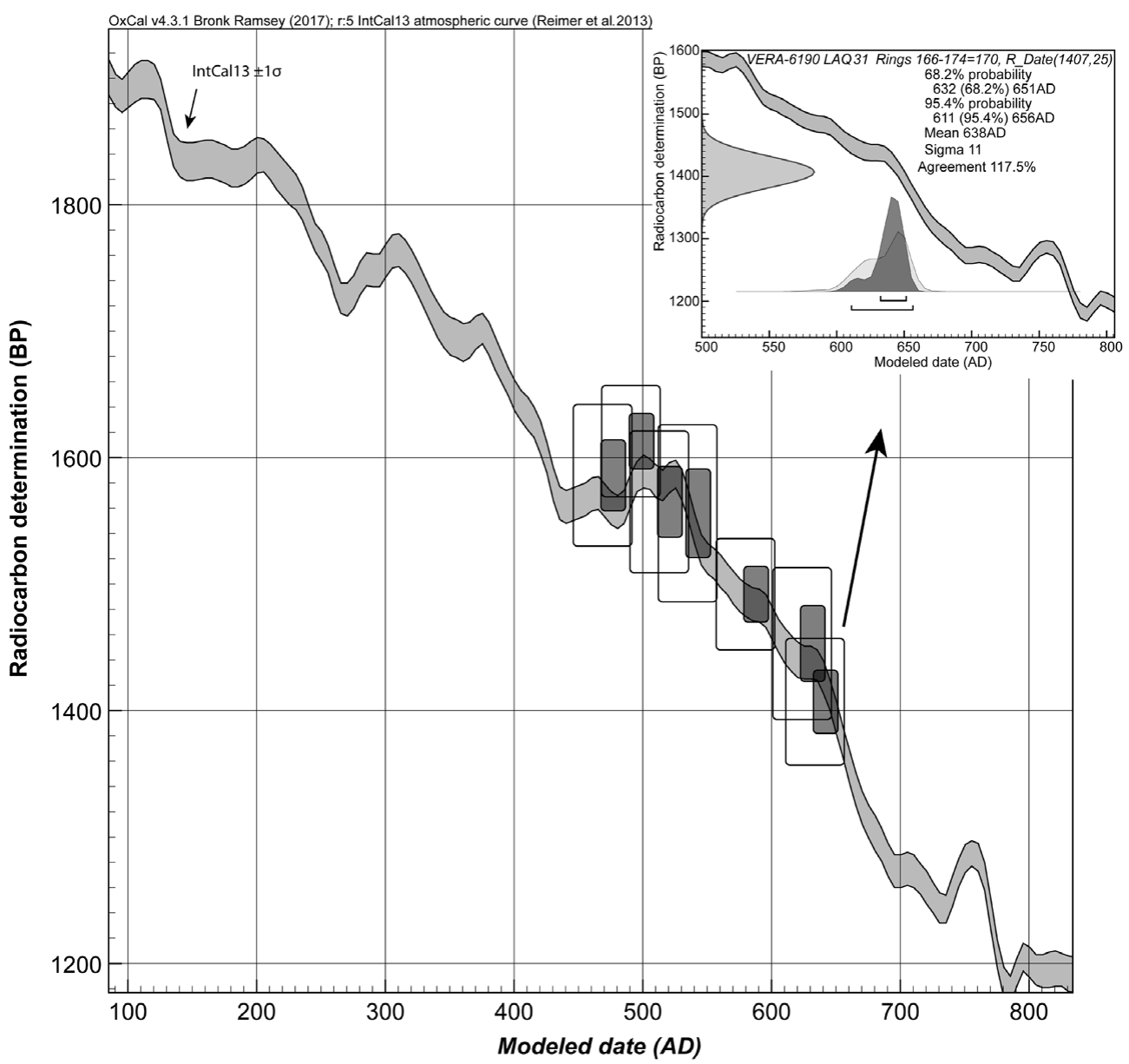

Figure 7. Radiocarbon wiggle-match of LAQ 31. Main panel: placement of the tree-ring sequenced ring segments of LAQ 31 on the IntCal13 radiocarbon calibration curve (Reimer et al. 2013). The black boxes indicate the 68.2\% probability ranges of the ${ }^{14} \mathrm{C}$ dates $(y$ axis) and the modeled $68.2 \%$ highest posterior density (HPD) calibrated calendar age ranges ( $x$ axis). Inset: modeled calibrated calendar age probabilities for the midpoint (relative year [RY] 170) of the last dated tree-ring sample from LAQ 31 (RY 166-174). The last extant tree ring from the LAQ 31 sample (RY 174) is four years later than this midpoint. Data from OxCal 4.3.1 (Bronk Ramsey 2009a).

order. The radiocarbon wiggle-match methodology supports the cross-dating of the two chronologies and relative order by placing them in absolute time.

As mentioned above, longer sequences have the greatest potential for successful wigglematching. Sample LAQ 31 from Room K of the La Quemada Cuartel, where LAQ 30 was also found, was selected because it contains 174 rings, its outer ring is very close to the waney edge, and it is a Type III pine variety. After ring widths were measured, seven treering segments were dissected, each variously of 9-11 years but with known tree-ring intervals between them. The resultant ${ }^{14} \mathrm{C}$ ages were then fitted against IntCal13 (Figure 7 and Table 3; Reimer et al. 2013). Application of the wigglematch methodology placed the end of the sample sequence (RY 1174, four years later than the midpoint of the last dated tree-ring sample) at cal AD 636-655 (68.2\% HPD).

The wiggle-match of the LAQ 31 radiocarbon dates explained the lack of cross dating between it and the Los Pilarillos and La Quemada chronologies, and most other ${ }^{14} \mathrm{C}$-dated samples, because its absolute dates do not overlap the time period represented by the other samples. Another sample, LAQ 35, the only sample from 


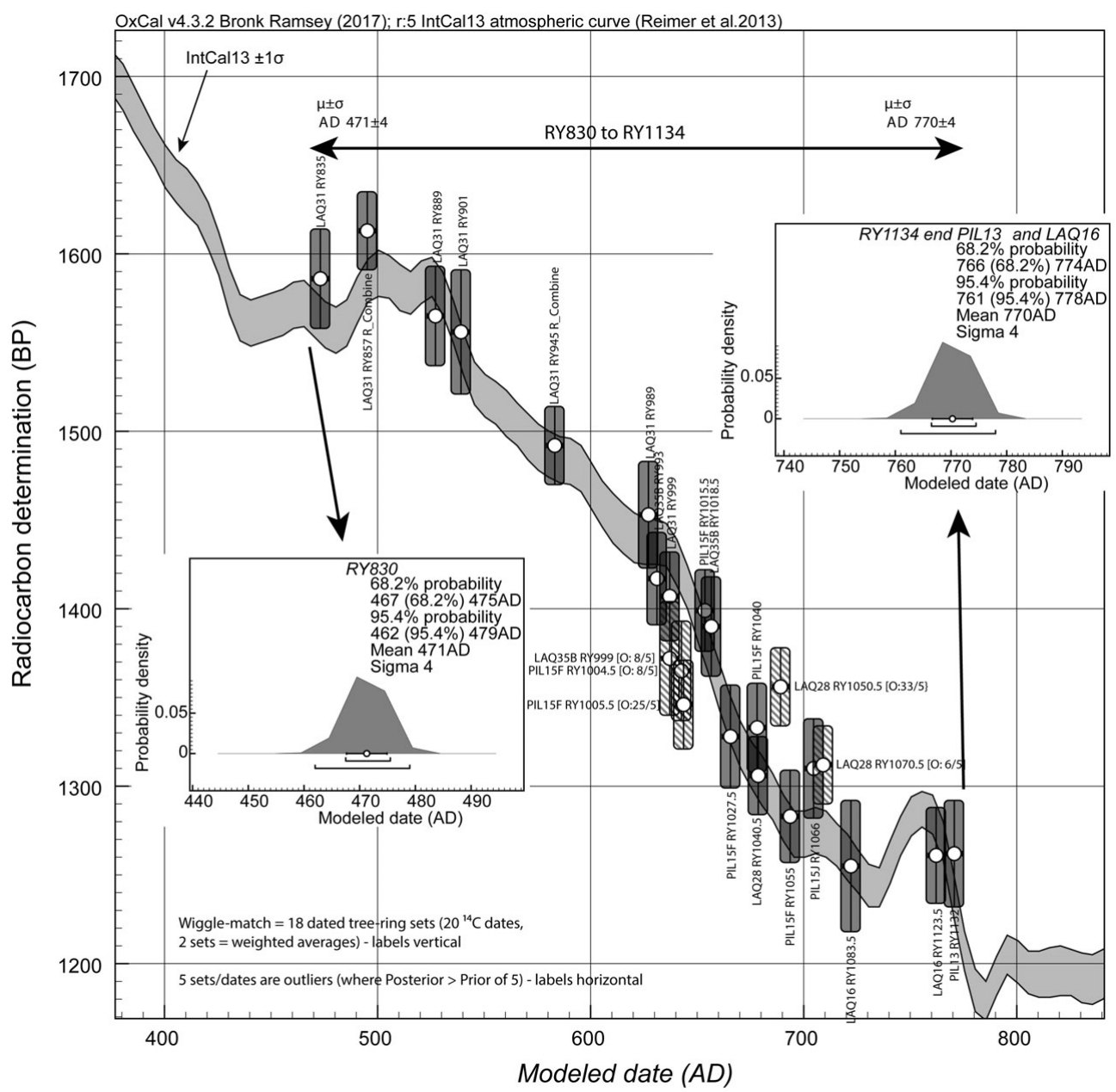

Figure 8. Radiocarbon wiggle-match of all the tree-ring sequenced radiocarbon dates on the combined LAQ and PIL chronology best fitted to the IntCal13 radiocarbon calibration curve (Reimer et al. 2013) employing OxCal 4.3 (Bronk Ramsey 2009a; Bronk Ramsey et al. 2001). The five cross-hatched dates are identified as outliers by the simple outlier model in OxCal (Bronk Ramsey 2009b). The model rerun without these outliers shows excellent agreement, with OxCal $A_{\text {model }}$ and $A_{\text {overall }}$ values of respectively 193.5 and 195.2, well above the satisfactory threshold value of 60 . The span of the Los Pilarillos and La Quemada chronologies is from RY 830 to 1134 . The modeled calendar age probability distributions, the $68.2 \%$ and $95.4 \%$ most likely ranges, and the mean $(\mu) \pm$ standard deviation $(\sigma)$ for the first and last tree rings in the chronology from the rerun minus outliers are shown as insets and above.

the Terrace 18 temple at La Quemada, contained only 40 rings and likewise did not cross-date with either LAQ 31 or the combined site chronologies. Nonetheless, the wiggle-match of three ${ }^{14} \mathrm{C}$ dated segments from the Terrace 18 sample places it tentatively between the LAQ 31 sample and the two site chronologies (Figures 6 and 8). Finally, the placement of a second tentative cross date, between LAQ 16 and the Los Pilarillos chronology, was supported by the ${ }^{14} \mathrm{C}$ wigglematching. The outer samples of the two site chronologies and LAQ 16 all contain close-towaney edges and end at approximately the same year, suggesting their construction was around the same time.

\section{Wiggle-Matching the Combined Samples}

The error range can be even further reduced, and cross dating further confirmed, by coordinating more of the ${ }^{14} \mathrm{C}$ dates from the La Quemada and Los Pilarillos samples. Using the relative dates from the tree-ring sequences in Figure 6a, 
a wiggle-match based on 25 radiocarbon dates along the complete chronology significantly reduces the dating fit range to \pm 4 calendar years ( $\mu \pm \sigma$ of the wiggle-match posterior density distribution; Figure 8). Five dates do not neatly fit on the radiocarbon calibration curve and are possible outliers, though their exclusion does not significantly alter the dates obtained from employing all $25{ }^{14} \mathrm{C}$ dates-moving the mean $(\mu)$ fit point for the start of the treering chronology two years older. The "cleaned" wiggle-match places the 305-year chronology at cal $\mathrm{AD} 466$ to $770 \pm 4$, which places the dates for minimal occupation at cal AD 639 to after 770 , with the construction events at La Quemada occurring soon after cal AD 639, 661, 711, 726, and 770 (RY 1003, 1025, 1075, 1090, 1134, respectively; Table 3 and Figure 6) and a building construction after AD 770 for Los Pilarillos (RY 1134; Figure 8). All dates have a \pm 4 -year error quoting the $\mu \pm \sigma$ of the wiggle-match posterior density distribution. Conservatively, the overall 95.4\% HPD range is $-9 /+8$ years.

\section{Cross Dating between Pinus Types}

Even if they are contemporaneous, different species can have different climate responses so that their tree-ring growth patterns may not crossdate. While all our samples are Pinus spp., this possibility was a concern due to the multiple Pinus sp. types represented at both sites. As noted above and listed in Table 1, four types of pine species are represented in the collection, and the La Quemada samples include species Types I and III with the Los Pilarillos samples representing species Types II and IV and a few samples of Type III (Table 1). Samples of only Type I make up the La Quemada chronology of Cuartel Rooms E and K, and in the Los Pilarillos North Banquette chronology only Type II species are represented. The successful cross dating between the two chronologies indicates that Type I and II species have similar climate responses in their growth patterns. For species Types III and IV there is no supporting evidence of similar growth patterns between them or the other species types, but that is not necessarily an indicator of different growth responses. Other reasons for the unsuccessful cross dating of those samples may be differences in represented time periods and short overlaps, as indicated by the earlier dates of LAQ 31 and the short sample LAQ 35, or, perhaps, a stronger nonclimatic growth response in these samples that masks the climate signal in the parent trees. The latter reason is suggested by the absence of cross dates between all the Type IV samples from the same context at Los Pilarillos.

The total number of samples (25) is small, but the species distribution could be culturally significant. The exclusive use of Type I pines at La Quemada Cuartel Rooms E and $\mathrm{K}$ and Type II in the North Banquette of Los Pilarillos suggests that those particular species were each chosen for their respective buildings. Type III is the only type represented at both sites and suggests preference or availability, but the suggestion must be used with caution because only two samples of that type were found at each site. The chronological order of the types at La Quemada (from the early samples of Type III to the later of Type I) and the 174-year lifespan of LAQ 31, however, may indicate that species Type III was plentiful when the site was first settled but that its availability quickly became limited (although pine types are not distinguished, Elliott [2012] finds an overall stable use of wood in the Pinus genus during the La Quemada occupation). Whether the selection of the different types reflects cultural preferences for specific wood characteristics, availability of the species, or a combination of the two is unknown but worth further research.

\section{Discussion}

We have made significant progress in crossdating archaeological tree-ring samples and wiggle-matching their radiocarbon ages to place the resulting chronologies in real time and to begin to demonstrate the potential for tree-ring dating for the first millennium AD in northwestern Mexico. If we make the assumption that the last extant rings on all but one sample are close to or at the bark and therefore within a few years of the felling date, we offer the following preliminary chronological findings and possible cultural interpretations. All of the cal AD dates 
below have \pm 4 range and represent the $\mu \pm \sigma$ dates from the tree-ring chronology in Figure 6 and the wiggle-match in Figure 8.

\section{The Cuartel}

Both ring measurement and wiggle-match results show that three beams from Rooms $\mathrm{E}$ and $\mathrm{K}$ within the Cuartel complex (LAQ 28-30) were cut within $\sim 20$ years of each other, after cal AD $711 \pm 4$ for Room $\mathrm{E}$ and for Room $\mathrm{K}$ after cal $\mathrm{AD} 726 \pm 4(\mu \pm \sigma)$. One beam from the same room (LAQ 31) suggests an earlier construction, after cal AD $639 \pm 4(\mu \pm \sigma)$. Given the size, strength, and good preservation of these samples, we assume that they were used as roof support beams. Room K in particular was a multistory interior room (Santos Ramírez 2014), which would have required substantial structural support. The fact that the two samples (LAQ 30 and 31) were found side by side in the same context, but the preserved tree rings and likely use dates are as much as 100 years apart, could support the remodeling interpretation proposed by Santos Ramírez (2014). Perhaps the early beam was used during the initial construction phase, after cal $\mathrm{AD} 639 \pm 4(\mu \pm \sigma)$, and due to its good condition was recycled during the second construction phase when the other beams were cut, sometime after cal AD $726 \pm 4$ $(\mu \pm \sigma)$.

In terms of a broader chronological interpretation regarding the Cuartel's construction within the structural development of the site of La Quemada, our chronological evidence, compared with other radiocarbon dates from other researchers, suggests that the Cuartel dates fit within the broad range of dates suggested previously (AD 500-800; Nelson 1997; Trombold 1990). More specifically, the later part of this wide range, after circa cal AD 639 to after circa cal $\mathrm{AD} 770$, is consistent with the reanalysis of Nelson's (1997) radiocarbon dates shown in Figure 3 . These dates, combined with the prominent location of the Cuartel and its proximity to the central core, support the hypothesis that the Cuartel is one of the earliest constructions at La Quemada (Santos Ramírez 2014). The tree-ring ${ }^{14} \mathrm{C}$ wiggle-match date indicate that the reconstruction of the Cuartel (around cal AD 770 \pm 4 ) potentially coincides with the beginning of the Terrace 18 construction episode during the late eighth century AD. We emphasize that this interpretation is based on minimal data and should be used only as a hypothesis to be tested by future information, and not to reorient the regional chronology.

The last extant tree ring in a sample from a possible beam in the temple on Terrace 18 (LAQ 35) dates to cal AD $661 \pm 4$. Previously published dates from the immediate surrounding architecture in the same room (Nelson et al. 1997) indicated a range between approximately cal AD 600 and 740. In comparison, the LAQ 35 date seems like a plausible initial construction date. This TPQ date is consonant with the most likely modeled calendar age range for the corncob (B-77239) found at the base of the Terrace 18 construction (cal AD 660-723, 65.8\% HPD range, shown in Figure 3). If our new dates are representative of cutting and building, then these dates for Terrace 18 are also consistent with the early date from the Cuartel, suggesting widespread site construction within a few years.

\section{Los Pilarillos}

As Los Pilarillos is substantially smaller than La Quemada, although still more elaborately built than most other valley sites, the relationship between the two is of particular interest to understanding Malpaso Valley cultural dynamics. Dendrochronology measurements and cross dating (Figures 6 and 8) place samples PIL 13 and PIL 21 from roof fall in a large room on the highest mound at cal AD $770 \pm 4(\mu \pm$ $\sigma)$, about 50-100 years later than the majority of beams in the Cuartel (LAQ 28-31) and the Terrace 18 temple construction. This later date is consistent with two interpretations. First, the monumental architecture at Los Pilarillos could have been built significantly later than the Cuartel and Terrace 18. In fact, PIL 15 (the other sample included in the cross date) while earlier than the other two Los Pilarillos samples, may indicate later construction than the La Quemada dates due to its lack of waney edge and context. Second, since these dates are from roof construction, we must consider this context most vulnerable to degradation due to exposure to weather, and therefore the beam might have needed to be replaced after initial 
construction. The hypothesis that Los Pilarillos was constructed more than 100 years after $\mathrm{La}$ Quemada may soon be addressed by ceramic seriation studies, which have identified some time-sensitive ceramic markers (Torvinen et al. 2015). The contemporaneity of LAQ 16 indicates that La Quemada was still occupied at the time of the settlement of Los Pilarillos, but the single LAQ sample and its limited context do not allow further interpretation.

The successful cross dating of samples within each site and between the two site chronologies, plus the tentative placements of the single samples, all suggested and validated by their ${ }^{14} \mathrm{C}$ dates, is an indication that with more samples, tree-ring measurements, cross dating, and ${ }^{14} \mathrm{C}$ dating, a better understanding of chronological changes in the region is possible. Additional samples will augment the tree-ring data to form a reference chronology against which new samples can be cross-dated. A reference chronology is expected to correlate with tree-ring data from other sites in a larger region that can be used to reconstruct construction sequences and spatial and temporal relationships between sites. The construction of a robust chronology also will be the basis for the next step in this project, to provide a regional record of climatic variability recorded in the ancient tree rings to reconstruct past environmental conditions.

\section{Conclusion}

Although preliminary, these studies have produced optimistic results that dendrochronological methods are a viable source of study for northwest Mesoamerica and have the potential to address questions that require finescale chronologies that still elude archaeologists. Despite the fact that some of the cross-dated placements of wood samples from the Malpaso Valley are tentative due to the lack of sufficiently overlapping sequences, the confirmation of these placements by the ${ }^{14} \mathrm{C}$ wiggle-match method is encouraging support that the placements are correct within a minor range of error. For example, these data suggest that the Hall of Columns-like structure at the site of Los Pilarillos was constructed about 50-100 years later than parts of $\mathrm{La}$ Quemada. Continued work with this collection and the addition of samples from new contexts, new sites, and neighboring regions, all of which we have initiated, should in the future provide a reference chronology that can be used to address more of these chronological questions.

Of course, the cultural interpretation is only as good as the data. Dendrochronological methods, even when they work perfectly, date the specific time at which the tree was cut down. Archaeologists must continue to interpret these dates with consideration of the culture and broader contexts in which the samples are found. In addition, one or more reference chronologies against which additional individual samples can be dated become more robust with potential for paleoclimatic analysis. In noting the need to expand the application, we conclude by taking advantage of this audience of practicing archaeologists with an offer to examine any archaeological wood that you may have from your excavations in this region. Although the method is partially destructive, the potential payoff is huge. With enough rings, samples may provide chronological data for your own sites and also contribute to an understanding of the prehistory of this dynamic region of Mesoamerica.

Acknowledgments. This work is supported by NSF Grant \#BCS-1324106 and is a collaboration between Ithaca College, Cornell University, Arizona State University, the Instituto Nacional de Antropología e Historia (INAH Oficio 401.B(4)19.2014/36/0834), and the Laboratorio de Anillos de Arboles at the Instituto Nacional de Investigaciones Forestales Agrícolas y Pecuarias (INIFAP). In particular, we thank José Villanueva Díaz, Julián Cerano-Paredes, Brita Lorenzen, and Michelle Elliott for dendrochronological and wood identification help. Alexandra Jiggetts-O'Neill, Katherine Seufer, Daniel Weller, Zoe Carlson, Sarah Butler, and James Landahl made indispensable contributions to field and laboratory work. Thanks also to Oralia Cabrera Cortés for preparing the Spanish abstract.

Data Availability Statement. The wood and charcoal samples, as well as the digital data, analyzed in this paper are held at the Cornell University Tree-Ring Laboratory. Please contact the authors for more information.

\section{References Cited}

Armillas, Pedro

1963 Investigaciones arqueológicas en el estado de Zacatecas. Boletín de INAH 14:16-17.

1964 Condiciones ambientales y movimientos de pueblos en la frontera septentrional de Mesoamerica. In 
Homenaje a Fernando Márquez-Miranda: Arqueólogo e Historiador de América, pp. 62-82. Seminario de Estudios Americanistas, University of Madrid, Madrid; Seminario de Antropología Americana, University of Seville, Seville.

Bannister, Bryant, and Stuart D. Scott

1962 Dendrochronology in Mexico. Proceedings of the XXXV International Congress of Americanists, Mexico, pp. 211-216. International Congress of Americanists, Mexico City.

Bayliss, Alex

2007 Bayesian Buildings: An Introduction for the Numerically Challenged. Vernacular Architecture 38:75-86.

Beekman, Christopher S.

2010 Recent Research in Western Mexican Archaeology. Journal of Archaeological Research 18:41-109.

Braniff, Beatriz, and Marie Areti-Hers

1998 Herencias Chichimecas. Arqueología 19:55-80.

Brewer, Peter W.

2014 Data Management in Dendroarchaeology Using Tellervo. Radiocarbon 56:79-83.

Bronk Ramsey, Christopher

2009a Bayesian Analysis of Radiocarbon Dates. Radiocarbon 51:337-360.

2009b Dealing with Outliers and Offsets in Radiocarbon Dating. Radiocarbon 51:1023-1045.

2017 OxCal Version 4.3.1 and 4.3.2. https://c14.arch.ox. ac.uk/oxcal.html, accessed March-April 2017.

Bronk Ramsey, Christopher, Johannes van der Plicht, and Bernhard Weninger

2001 'Wiggle Matching' Radiocarbon Dates. Radiocarbon 43:381-389.

Brown, Roy B.

1992 Arqueología y Paleoecología del Norcentro de México. 1st ed. Serie Arqueología. Instituto Nacional de Antropología e Historia, Mexico City.

Burns, Jordan N., Rodolfo Acuna-Soto, and David W. Stahle

2014 Drought and Epidemic Typhus, Central Mexico, 1655-1918. Emerging Infectious Diseases 20:442447.

Cleaveland, Malcom K., David W. Stahle, Matthew D. Therrell, José Villanueva-Diaz, and Barney T. Burns

2003 Tree-Ring Reconstructed Winter Precipitation and Tropical Teleconnections in Durango, Mexico. Climatic Change 59:369-388.

Comisión Nacional del Agua

2008 Estadísticas del Agua en México. Comisión Nacional del Agua, Coyoacán, Mexico City.

Cook, Edward R., and Leonardes Kairiukstis

1990 Methods of Dendrochronology: Applications in the Environmental Sciences. Kluwer Academic Publishers, Dordrecht, the Netherlands.

Cook, Edward R., Connie A. Woodhouse, C. Mark Eakin, David M. Meko, and David W. Stahle

2004 Long-Term Aridity Changes in the Western United States. Science 306:1015-1018.

Elliott, Michelle

2012 An Anthracological Approach to Understanding Late Classic Period Cultural Collapse in Mesoamerica's Northwestern Frontier. In Wood and Charcoal: Evidence for Human and Natural History, edited by Ernestina Badal, Yolanda Carrión, Miguel Macías, and María Ntinou, pp. 217-226. SAGVNTVM: Papeles del Laboratorio de Arqueología de Valencia, Valencia.
Elliott, Michelle, Christopher T. Fisher, Ben A. Nelson, Roberto S. Molina Garza, Shawn K. Collins, and Deborah M. Pearsall

2010 Climate, Agriculture and Cycles of Human Occupation over the Last 4,000 Years in Southern Zacatecas, Mexico. Quaternary Research 74:26-35.

Evans, Susan T., and David L. Webster (editors)

2001 Archaeology of Ancient Mexico and Central America: An Encyclopedia. Garland Publishing, New York.

Frederick, Charles D.

1995 Fluvial Response to Late Quaternary Climate Change and Land Use in Central Mexico. PhD dissertation, Department of Geography, University of Texas, Austin.

Fritts, Hal C.

1976 Tree Rings and Climate. Academic Press, London.

Galimberti, Mariagrazia, Christopher Bronk Ramsey, and Sturt W. Manning

2004 Wiggle-Match Dating of Tree Ring Sequences. Radiocarbon 46:917-924.

González-Elizondo, Martha, Enrique Jurado, José Návar, M. Socorro González-Elizondo, José Villanueva, Oscar Aguirre, and Javier Jiménez

2005 Tree-Rings and Climate Relationships for DouglasFir Chronologies from the Sierra Madre Occidental, Mexico: A 1681-2001 Rain Reconstruction. Forest Ecology and Management 213:39-53.

Holmes, Richard

1983 Computer-Assisted Quality Control in Tree-Ring Dating and Measurement. Tree-Ring Bulletin 43:69-78.

IRI/LDEO Climate Data Library

2016a Tree-Ring Reconstructed Drought, Grid Point: 121 107.5W 30.0N. International Research Institute for Climate and Society, Earth Institute, Columbia University, Palisades, New York.

2016b Tree-Ring Reconstructed Drought, Grid Point: 106 110.0W 30.0N. International Research Institute for Climate and Society, Earth Institute, Columbia University, Palisades, New York.

Jiménez Betts, Peter

2004 Guía de Viajeros, La Quemada, Zacatecas. Arqueología Mexicana 67:80-87.

Kennett, Douglas, Irka Hajdas, Brendan J. Culleton, Soumaya Belmecheri, Simon Martin, Hector Neff, Jaime Awe, Heather V. Graham, Katherine H. Freeman, Lee Newsom, David L. Lentz, Flavio S. Anselmett, Mark Robinson, Norbert Marwan, John Southon, David A. Hodell, and Gerald H. Haug

2013 Correlating the Ancient Maya and Modern European Calendars with High-Precision AMS ${ }^{14} \mathrm{C}$ Dating. Scientific Reports 3. doi:10.1038/srep01597.

Lelgemann, Achim

2000 Informe Final: Proyecto Ciudadela de La Quemada, Zacatecas. Instituto Nacional de Antropología e Historia, Mexico City.

Martínez, Maximo

1948 Los Pinos Mexicanos. 2nd ed. Ediciones Botas, Mexico City.

Naylor, Thomas H.

1971 Dendrochronology in Oaxaca, Mexico: A Preliminary Study. Tree-Ring Bulletin 31:25-29.

Nelson, Ben A.

1997 Chronology and Stratigraphy at La Quemada, Zacatecas, Mexico. Journal of Field Archaeology 24:85-109. 
2001 Aggregation, Warefare, and the Spread of the Mesoamerican Tradition. In The Archeology of Regional Interaction: Religion, Warfare, and Exchange Across the American Southwest and Beyond, edited by Michelle Hegmon, pp. 317-337. University of Colorado Press, Boulder.

2004 Current and Future Directions in the Archaeology of Northwest Mexico. In Surveying the Archaeology of Northwest Mexico, edited by Gillian E. Newell and Emiliano Gallaga, pp. 289-296. University of Utah Press, Salt Lake City.

Nelson, Ben A., John Millhauser, and Denise To

1997 Burial Excavations in Plaza 1 of Los Pilarillos, Zacatecas, Mexico, 1997 Season. Report submitted to the Foundation for the Advancement of Mesoamerican Studies. Department of Anthropology, Arizona State University, Tempe.

Nelson, Ben A., and Vincent W. Schiavitti

1992 Trabajos Conducidos por la State University of New York at Buffalo dentro del Proyecto La Quemada 1989-90. Instituto Nacional de Antropología e Historia, Mexico City.

Nelson, Ben A., Paula D. Weintraub, and Vincent W. Schiavitti

1993 Informe Parcial del Proyecto Valle de MalpasoLa Quemada Temporada 1992. Instituto Nacional de Notimex Antropología e Historia, Mexico City.

2013 Arqueólogos del INAH hallan restos orgánicos de 1,100 años en Zacatecas. Expansión, August 27. Electronic document, http://expansion.mx/entretenimiento/ 2013/08/27/arqueologos-del-inah-hallan-restosorganicos-de-1100-anos-en-zacatecas, accessed October 17, 2017.

Parlerm, Ángel, and Eric R. Wolf

1957 Ecological Potential and Cultural Development in Mesoamerica. In Studies in Human Ecology: A Series of Lectures Given at the Anthropological Society of Washington, Social Science Monographs III, pp. 1-37. Pan American Union, Washington, DC.

Reimer, Paula J., Edouard Bard, Alex Bayliss, Warren Beck, Paul G. Blackwell, Christopher Bronk Ramsey, Caitlin E Buck, Hai Cheng, R. Lawrence Edwards, Michael Friedrich, Pieter M. Grootes, Thomas P. Guilderson, Haflidi Haflidason, Irka Hajdas, Christine Hatté, Timothy J. Heaton, Dirk L. Hoffmann, Alan G. Hogg, Konrad A. Hughen, K. Felix Kaiser, Bernd Kromer, Sturt W. Manning, Mu Niu, Ron W. Reimer, David A Richards, E. Marian Scott, John R. Southon, Richard A. Staff, Christian S. M. Turney, and Johannes van der Plicht

2013 IntCal13 and Marine13 Radiocarbon Age Calibration Curves 0-50,000 Years cal BP. Radiocarbon 55:1869-1887.

Santos Ramírez, Marco Antonio

2014 Informe Final de los Temporadas 2012-2014 Proyecto Arqueológico La Quemada. Instituto Nacional de Antropología e Historia, Mexico City.

Schweingruber, Fritz Hans

1988 Basics and Applications of Dendrochronology. Springer, Dordrecht, the Netherlands.

Scott, Stuart D.

1966 Dendrochronology in Mexico. University of Arizona Press, Tucson.
Schulman, Edmund

1944 Dendrochronology in Mexico, I. Tree-Ring Bulletin 10:18-24.

Soler Arechalde, Ana María, Cecilia Caballero Miranda, Jaime Urrutia Fucugauchi, and Avto Gogichaishvili

2011 Contribuciones del arqueomagnetism para el fechamiento en Mesoamérica. In Escenarios de cambio climático: Registros del Cuaternario en América Latina I, edited by Margarita Caballero and Beatriz Ortega Guerrero, pp. 340-365. Universidad Nacional Autónoma de México, Mexico City.

Speer, James H.

2010 Fundamentals of Tree-Ring Research. University of Arizona Press, Tucson.

Stahle, David W.

1999 Useful Strategies for the Development of Tropical Tree-Ring Chronologies. IAWA Journal 20:249253.

Stahle, David W., Dorian J. Burnette, Jose Villanueva, Julian Cerano, Falko K. Fye, R. Daniel Griffin, Malcolm K. Cleaveland, Daniel Stahle, Jesse R. Edmondson, and Kathryn P. Wolff

2012 Tree-Ring Analysis of Ancient Baldcypress Trees and Subfossil Wood. Quaternary Science Reviews 34:115.

Stahle, David W., and Malcom K. Cleaveland

1993 Southern Oscillation Extremes Reconstructed from Tree Rings of the Sierra Madre Occidental and Southern Great Plains. Journal of Climate 6:129-140.

Stahle, David W., Edward R. Cook, Dorian J. Burnette, Jose Villanueva, Julian Cerano, Jordan N. Burns, Daniel Griffin, Benjamin I. Cook, Rodolfo Acuña, Max C.A. Torbenson, Paul Szejner, and Ian M. Howard

2016 The Mexican Drought Atlas: Tree-ring reconstructions of the soil moisture balance during the late pre-Hispanic, colonial, and modern eras. Quaternary Science Reviews, 149:34-60.

Stahle, David W. Jr., José Villanueva Diaz, Dorian J. Burnette, Julian Cerano Paredes, Richard R. Heim, Falko K. Fye, Rodolfo Acuna Soto, Matthew D. Therrell, Malcolm K. Cleaveland, and David K. Stahle

2011 Major Mesoamerican Droughts of the Past Millennium. Geophysical Research Letters 38:L05703.

Torreblanca Padilla, Carlos Alberto

2014 La sala hipóstila de El Cóporo, Guanajuato: Un espacio arquitectónico en el norte de México. In Tiempo y Región: Estudios Históricos y Sociales, Vol. VII, edited by Carlos Viramontes Anzures, pp. 97-116. Instituto Nacional de Antropología e Historia, Mexico City; Universidad Autónoma de Querétaro, Querétaro; Municipio de Querétaro, Querétaro.

Torvinen, Andrea, Stephanie Kulow, and Ben Nelson

2015 Refinement of the La Quemada Chronology and Its Implications for Inter-Polity Interaction along the Northern Frontier of Mesoamerica. Paper presented at the 80th Annual Meeting of the Society for American Archaeology, San Francisco, California.

Torvinen, Andrea, Ben Nelson, Chloe Pomedio, and Nora Rodriguez

2014 Developing Regional Chronologies Using Ceramic Metatypologies: An Example from Northwest Mexico. Paper presented at the 79th Annual Meeting of the Society for American Archaeology, Austin, Texas. 
Trombold, Charles D.

1985 A Summary of the Archaeology of the La Quemada Region. In The Archaeology of West and Northwest Mexico, edited by Michael S. Foster and Phil C. Weigand, pp. 327-352. Westview Press, Boulder, Colorado.

1990 A Reconsideration of the Chronology for the La Quemada Portion of the Northern Mesoamerican Frontier. American Antiquity 55:308-324.

Trombold, Charles D., and Isabel Israde-Alcantara

2005 Paleoenvironment and Plant Cultivation on Terraces at La Quemada, Zacatecas, Mexico: The Pollen, Phytolith and Diatom Evidence. Journal of Archaeological Science 32:341-353.

Turkon, Paula, Michelle Elliott, Sturt W. Manning, and Carol Griggs

2011 Dendrochronology, Chronological Control, and Climate Reconstruction in Northwest Mesoamerica. Paper presented at the 76th Annual Meeting of the Society for American Archaeology, Sacramento, California.

Turkon, Paula, Sturt W. Manning, Carol B. Griggs, and Alexandra Jiggetts-O'Neill

2015 Season 2 Results: Dendro- ${ }^{14} \mathrm{C}$-WiggleMatching in Northwestern Mesoamerica. Paper presented at the 80th Annual Meeting of the Society for American Archaeology, San Francisco, California.
Verheye, Willy $\mathrm{H}$.

2010 Growth and Production of Maize: Traditional LowInput Cultivation. In Soils, Plant Growth and Crop Production, Volume II, edited by Willy H. Verheye, pp. 69-100. EOLSS Publishers, Oxford.

Villanueva Díaz, José, Julián Cerano Paredes, David W. Stahle, Brian H Luckman, and Matthew D. Therrell

2002 Historical Droughts in North-Central Mexico. Electronic document. https://www.researchgate.net/ profile/Brian_Luckman/publication/237249739_ HISTORICAL_DROUGHTS_IN_NORTH-

CENTRAL_MEXICO/links/

00b7d52fbaef2dc8a2000000/HISTORICALDROUGHTS-IN-NORTH-CENTRAL-MEXICO.pdf, accessed November 8, 2017.

Weigand, Phil

1977 The Prehistory of the State of Zacatecas: An Interpretation. In Anuario de Historia Zacatecana, edited by C. Esparza Sanchez, pp. 1-41. Universidad Autonoma de Zacatecas, Zacatecas.

Zeidler, James A., Caitlin E. Buck, and Clifford D. Litton 1998 Integration of Archaeological Phase Information and Radiocarbon Results from the Jama River Valley, Ecuador: A Bayesian Approach. Latin American Antiquity 9:160-179.

Submitted October 22, 2016; Revised April 19, 2017;

Accepted September 22, 2017 